Vol. 5, No. 01; 2021

ISSN: 2581-3366

\title{
The Role of Tumor Necrosis Factor-alpha as a Marker of Inflammation and a Predictor of in-hospital Complications in Patients with Acute Coronary Syndrome
}

\author{
${ }^{1}$ Sally Abdul-Raheem Alhumrani * B.Sc Biology \\ ${ }^{2}$ Nidham M. Jamalludeen* M.Sc, PhD \\ ${ }^{3}$ Abdulameer Abdulbari Abdulhameed ${ }^{* *}$ FIBMS, CABM (Interventional Cardiologist) \\ *Department of Microbiology \\ College of Medicine \\ University of Basrah \\ Basrah, Iraq \\ ** Department of Medicine \\ College of Medicine \\ University of Basrah \\ Basrah, Iraq
}

doi: $10.51505 / \mathrm{ijmshr} .2021 .5112$

URL: http://dx.doi.org/10.51505/ijmshr.2021.5112

\section{Abstract \\ Background}

Acute coronary syndromes are caused by rupture of plaques or erosion that leads to local clotting formation of coronary blood flow eventually blocking to necrosis or ischemia of myocardial cells. Prognosis; other markers of inflammation may play similar role. Cytokines are responsible for modulating immune and inflammatory processes as well as both proliferative and apoptotic responses. Tumor necrosis factor (TNF- $\alpha$ ): It is an important cytokine involved in systemic inflammation. This study aimed to measure TNF- $\alpha$ level and its association with hospital complications in patients with the acute coronary syndrome.

Method:

One hundred and twenty-five patients with acute coronary syndrome and 120 healthy individuals as a control group

According to ECG and serum troponin changes, the patient group was classified into three; STelevated myocardial infarction, ST non-elevated myocardial infarction and unstable angina.

Sandwich ELISA was used by commercial groups (LEGAND MAXTM) for the TNF- $\alpha$ assay.

\section{Result:}

This study shows highly significant differences in the level of TNF-ain patient with acute coronary syndrome (27.49) as compared with the control group (10.62) (P. value 0.001)

There were no statistically significant differences in the level of TNF- $\alpha$ in patients with acute coronary syndrome and some traditional risk factors like gender (P. value 0.25$)$.

There were statistically significant differences in the level of TNF- $\alpha$ in all forms of ACS and control group p-value 0.001 


\section{International Journal of Medical Science and Health Research}

Vol. 5, No. 01; 2021

ISSN: 2581-3366

Patients with in hospital complication had higher level of TNF- $\alpha$ (33.46 Pgldl) than those without complication (24.15 Pgldl) P-value (0.041).

\section{Conclusion:}

This study indicated that TNF- $\alpha$ was significantly elevated in patients with ACS and maybe a good predictor not only of acute coronary event but also disease severity and prognosis for complications.

Keywords ACS, TNF- $\alpha$, STEMI, NSTEMI, unstable angina, complications

\section{Introduction:}

Inflammation plays a pivotal role not only in the chronic form of atherosclerosis (clinically manifested as stable angina) but also in acute coronary event (the acute coronary syndrome)

Acute coronary syndromes result from plaque rupture or erosion leading to local thrombus formation obstruction of coronary blood flow ultimately to necrosis or ischemia of cardiac myocyte. Cardiac troponin and $\mathrm{C}$ reactive protein is a good marker for diagnosis and prognosis; other markers of inflammation may play a great role as well.[1]

Cytokines are responsible for the modulation of immunological and inflammatory processes as well as proliferative responses and apoptosis.[2]

Tumor necrosis factor (TNF- $\alpha)$ : is one of the important cytokines involved in systemic inflammation and makes up the acute phase reaction. TNF- $\alpha$ is a potent pro-inflammatory cytokine exerting pleiotropic effects on various cell types and plays a critical role in the pathogenesis of chronic inflammatory diseases, such as Rheumatoid arthritis. [3, 4]

It is produced chiefly by activated macrophages, although it can be produced by many other cell types such as CD4+ lymphocytes, NK cells, neutrophils, mast cells, eosinophils, and neurons. It also synthesized in various blood, endothelial and smooth muscle cells, and in cardiac myocytes. [5]

The presence of TNF- $\alpha$ in the majority of atherosclerotic lesions and absence from normal tissues suggests its involvement in the pathogenesis of atherosclerosis. TNF- $\alpha$ may contribute to the inflammatory process of atherosclerosis by activation of growth factors, other cytokines, and by affecting the synthesis and stimulation of adhesion molecules. [6]

The ubiquity and function of its 2 receptors provide it with the capacity to modulate acute coronary diversity of inflammatory processes which are strongly involved in acute coronary syndrome (ACS) [7] and in the development of heart failure due to its negative inotropic action. [8], Therefore this study aimed to measure the level of TNF- $\alpha$ in patients with ACS and study their role as an early marker of inflammation in the indifferent form of ACS, whether it correlates with in-hospital complications 


\section{International Journal of Medical Science and Health Research}

Vol. 5, No. 01; 2021

ISSN: 2581-3366

\section{Method}

One hundred twenty-five patients with acute coronary syndrome and 120 persons as a control group were included in this study for the period from March 2019 to January 2020.Their age range from 31 to 95 with mean $(58.72 \pm 12.32 \mathrm{SD})$. Ethical approval was getting from the committee board of the Iraqi health and higher education authority before start collection the samples.

Fifty-seven (45.6\%) were females and $68(54.4 \%)$ were males. A review of history was taken, Physical examinations were done. Routine blood count and serum biochemistry were requested

Twelve leads Electrocardiography was done and review by expert cardiologists. According to electrocardiography changes and serum troponin, the patients group was sub-classified into three subgroups ST-elevation myocardial infarction (STEMI), Non-ST-elevation myocardial infarction (NSTEMI), and unstable angina(UA) groups.

Five $\mathrm{ml}$ of venous blood samples where obtained from all patients at time of admission to CCU at Albasrah teaching hospital and Alsader teaching hospital and prepared for TNF- $\alpha$ level assay.

Sandwich ELISA was used by commercial kits (LEGAND MAX TM) for TNF- $\alpha$ assay. The procedure was performed according to kit manufacture instruction company and ELISA done in the Albian lab.

\section{Statistical Analysis}

The data were analyzed SPSS version 17. Means and standard deviation were used to describe the data distribution. ANOVA or F-test was used for the comparison of more than two means, when analysis significant, Post hoc test used to determine within the group analysis significantly. Independent t-test used to determine significance between the means of two groups. The test was considered significant if the P. value was less than 0.05 .

\section{Result:}

Out of 125 patients with ACS; STEMI was the commonest form reported 75 (60\%) patients, followed by UA 29 (23.3\%) patients, and NSTEMI 21 (16.8\%) patients.

This study demonstrated a high level of TNF- $\alpha$ in patients with ACS (27.49 Pg/dl) than the control group (10.62 Pg/dl). This difference was statistically highly significant (P. value 0.001).

All form of ACS (STEMI, NSTEMI and UA) have higher TNF- $\alpha$ levels in comparism with the control group. (Table 1)

There were no astatically significant differences in the level of TNF- $\alpha$ when different form of ACS compare with each other (STEMI Vs NSTEMI, STEMI Vs UA, and NSTEMI Vs UA)

P.value; $(0.95,0.19$, and 0.70 respectively)

This study demonstrated that there were no statistically significant differences between the traditional risk factors that were studied (age, smoking, hypertension, diabetes .mellitus, obesity) and the level of TNF- $\alpha$ in patient with ACS. (Table2). 


\section{International Journal of Medical Science and Health Research}

Vol. 5, No. 01; 2021

ISSN: 2581-3366

There were statistically significant differences in the mean level of TNF- $\alpha$ in patients with complication (33.46pg/dl) and without complication (24.15pg/dl) in ACS

(P. value 0.041) (Table 3)

Despite heart failure was the commonest complication in the patients that were studied, there were no significant differences between the mean level of TNF- $\alpha$ in patients with heart failure versus those patients with other complications $(\mathrm{P}$. value $=0.897)$. (Table 4)

Another interesting finding this study reported there were no statistically significant differences on the effect of gender on TNF- $\alpha$ level among different form of ACS

(P. value 0.210) (Table 5)

\section{Discussion:}

The roles of pro-inflammatory and anti-inflammatory cytokine in the pathogenesis of the disease get great consideration in recent studies. A balance between proinflammatory and antiinflammatory cytokines is necessary to maintain health. [9]

Although several cytokines (IL-1 $\beta$, IL-6, IL- 23, IL-27, IL-33), associated with an increased risk of atherosclerosis. [10]

Low level of interleukin-10 (as anti-inflammatory cytokine), have been associated with an increased risk of cardiovascular events and high IL-10 level have been associated with a decreased risk of ACS [11,12]

The role of the pro-inflammatory cytokine TNF- $\alpha$ in ACS was the focus of our concern in this study.

TNF- $\alpha$ level was significantly elevated in patients with ACS (27.49 pg/dl) than control group $(10.62 \mathrm{pg} / \mathrm{dl})$ (p. value 0.001) (Table 1).This was in agreement with other studies [13-16]

Ridker et al., have reported that plasma concentration of TNF- $\alpha$ remains elevated many months after myocardial infarction and that very high levels are associated with an increased risk of recurrent coronary events [17]

Recently, it is believed that TNF- $\alpha$ is one of the main proinflammatory cytokines and plays a central role in initiating and regulating the cytokine cascade during an inflammatory response and plays an important role in the pathogenesis of atherosclerosis and acute coronary syndromes. [6]

Simon et al. were administered that increase the level of pro-inflammatory cytokine concentrations were important and also decrease the level of anti-inflammatory cytokine concentrations in patients with ACS as well. [18]

Other authors reported that TNF- $\alpha$ increase in acute MI not only more than control but also more than patients with stable angina, their results had statistically significant differences. [19, 20] 


\section{International Journal of Medical Science and Health Research}

Vol. 5, No. 01; 2021

ISSN: 2581-3366

This might indicate that these cytokines had a role in acute events in addition to their role in the development of the chronic atherosclerotic process; the stable form of the disease (stable angina).

This study shows that despite hypertension is the commonest traditional risk factor,

$72(56.7 \%)$ patients. This study did not show any influence of hypertension on the level of TNF- $\alpha$ P. Value (0.73). (Table2). These were in agreement with other studies [21, 22]

Diabetes is the second most common risk factor in this study patient group with ACS

$65(52 \%)$ patients but there was no statistically significant influence of diabetes on the level of TNF-ain ACS patient group in comparison with non-diabetic. The P. values (0.945). This was inconsistent with others. [21, 22]

Thirty-six (28.8\%) patients enrolled in this study had complications.

There were statistically significant differences in the mean level of TNF- $\alpha$ between patients with complications (24.91pg\dl) and those without complications $(21.93 \mathrm{pg} / \mathrm{dl})$. (P. value 0.041$)$, this was in accordance with other studies. [22-24]

Other authors reported an increase in the level of TNF- $\alpha$ not only associated with increase complication but with the severity of disease and the number of vessels that severely involved (>50\%-70\% luminal narrowing on angiogram) $[23,24]$

Ridker PM. and Manuel G. reported that raise TNF- $\alpha$ not only associated with in-hospital complication but an independent predictor of cardiovascular events at 6-month follow-up. [17, 25]

Deswal et al indicated that TNF- $\alpha$ was an independent predictor of mortality in patients with heart failure. [8]

\section{Conclusion:}

This study indicated that TNF- $\alpha$ level was a good indicator of acute coronary events and predictor of severity and complications of the disease.

\section{References: -}

1- Trepels T., Zeiher AM., Fichtlscherer S., Acute coronary syndrome and inflammation. Biomarkers for diagnostics and risk stratification, 2004; 29(8):769-76

2- Bossowska A., Kiersnowska-Rogowska B., Bossowski A., Galar B., Sowiński P., Cytokines in patients with ischaemic heart disease or myocardial infarction, 2003; 59(8):105-14

3- Feldmann M., Maini RN., Anti-TNF alpha therapy of rheumatoid arthritis: what have we learned? Annu Rev Immunol. 2001; 19: 163-96

4- Bradley JR., TNF-mediated inflammatory disease. J Pathol. 2008; 214: 149-60. 


\section{International Journal of Medical Science and Health Research}

Vol. 5, No. 01; 2021

ISSN: 2581-3366

5- Irwin MW., Mak S., Mann DL., Penninger JM, Yan A, et al. Tissue expression and immunolocalization of tumor necrosis factor-alpha in postinfarction dysfunctional myocardium. Circulation, 1999; 99: p. 1492-8

6- Dedoussis GV., Panagiotakos DB., Vidra NV., Louizou E., Chrysohoou C., Germanos A., et al. Association between TNF-alpha $-308 \mathrm{G}>\mathrm{A}$ polymorphism and the development of acute coronary syndromes in Greek subjects. Genet Med. 2005; 7: 411-416

7- Barath P., Fishbein MC., Cao J., Berenson J., Helfand RH., Forrester JS., Detection and localization of tumor necrosis factor in human atheroma. Am J Cardiol, 1990; 65(5): p. 297-302

8- Deswal A., Petersen NJ., Feldman AM., Young JB., White BG., Mann DL., Cytokines and cytokine receptors in advanced heart failure: an analysis of the database from the vesnarinone trial (VEST). Circulation, 2001; 103: p. 2055-9

9- Scarpioni R., Ricardi M., Albertazzi V., "Secondary amyloidosis in autoinflammatory diseases and the role of inflammation in renal damage". World Journal of Nephrology.2016; 5 (1): 66-75

10- Ait-Oufella H., Taleb S., Mallat Z., Tedgui A., "Recent advances on the role of cytokines in atherosclerosis, Arteriosclerosis, Thrombosis, and Vascular Biology 2011; 31(5): p. 969979.

11- Anguera I., Miranda-Guardiola F., Bosch X., et al. Elevation of serum levels of the antiinflammatory cytokine interleukin-10 and decreased risk of coronary events in patients with unstable angina. Am Heart J. 2002; 144: 811-817

12- Heeschen C., Dimmeler S., Hamm CW., Fichtlscherer S., Boersma E., Simoons ML., Zeiher AM., Serum Level of the Antiinflammatory Cytokine Interleukin-10 Is an Important Prognostic Determinant in Patients With Acute Coronary Syndromes 2003;107:21092114

13- Gotsman A., David P., Thea P., Ludmila L., Yelena N., Siham M., Aubrey S DMD2 and Chaim L MD1 Serum cytokine tumor necrosis factor-alpha and interleukin-6 associated with the severity of coronary artery disease: Indicators of an active inflammatory burden? IMAJ 2008; 10 (7):494.

14- Nagendra B., Arulselvi S., Garima A., Sundeep M., Association of Cytokines IL6, IL10, IL18, TNFa in Acute Coronary Syndrome Arulselvi Subramanian. J Cardio Vasc Med 2019; 5: 1-9.

15- Maury CPJ., Teppo AM., "Circulating tumour necrosis factor- $\alpha$ (cachectin) in myocardial infarction," Journal of Internal Medicine, 1989; 225(5): p 333-336.

16- Liuzzo G., Buffon A., Biasucci LM., et al. "Enhanced inflammatory response to coronary angioplasty in protein in severe unstable angina," The New England Journal of Medicine, 1994; 331(7): p. 417-424, 1994. 
Vol. 5, No. 01; 2021

ISSN: 2581-3366

17- Ridker PM., Rifai N., Pfeffer M., Sacks F., Lepage S., Braunwald E., Elevation of tumor necrosis factor-alpha and increased risk of recurrent coronary events after myocardial infarction. Circulation 2000; 101:2149-53

18- SimonA., Yazdani S., Wang W., et al. Circulating levels of IL-1beta, a prothrombotic cytokine is elevated in unstable angina versus stable angina. J. Thromb. Thrombolysis. 2000; 9: 217-222

19- Biasucci L., Vitelli A., Liuzzo G., Elevated levels of interleukin-6 in unstable angina. Circulation. 1996; 94:874-877

20- Dybdahl B., Slordahl S., Waage A., et al. Myocardial ischemia and the inflammatory response: release of heat shock protein 70 after myocardial infarction. Heart. 2005; 91:299-304

21- Sunyer J., Forastiere F., Pekkanen J., Plana E., Kolz M., Pistelli R., et al. Interaction between smoking and the interleukin-6 gene affects systemic levels of inflammatory markers. Nicotine and tobacco research 2009; 11:1337-43

22- Tarek H., Atef A., Haitham H., The relation between interleukin-6 and different categories of acute coronary syndrome. Research and Opinion in Anesthesia \& Intensive Care 2015; 2:7-15

23- Cesari M, Penninx BW, Newman AB, et al. Inflammatory markers and cardiovascular disease. Am J Cardiol 2003; 92:522- 8

24- Gotsman A., Stabholz D., Planer et al., Serum cytokine tumor necrosis factor-alpha and interleukin-6 associated with the severity of coronary artery disease: indicators of an active inflammatory burden ISMAJ. 2008; 10(7): 494-498.

25- Manuel G., José A., Matías P., María L., Francisco J., et al., Prognostic value of tumor necrosis factor-alpha in patients with ST-segment elevation acute myocardial infarction cardiolgia; 2007; 60(12); 1233-1241. 
International Journal of Medical Science and Health Research

Vol. 5, No. 01; 2021

ISSN: 2581-3366

Table 1: The mean of TNF- $\alpha$ among different type of ACS

\begin{tabular}{|c|c|c|c|c|}
\hline & NO. of pts. & Mean of TNF- $\alpha$ & SD & Palue \\
\hline STEMI & 75 & 29.18 & 24.28 & \\
\hline NSTEMI & 21 & 26.66 & 19.60 & \multirow{2}{*}{$0.001^{*}$} \\
\hline $\begin{array}{c}\text { UNSTABLE } \\
\text { ANGINA }\end{array}$ & 29 & 20.76 & 21.93 & \\
\hline CONTROL & 120 & 9.21 & 6.47 & \\
\hline
\end{tabular}

Table 2 The relationship of TNF- $\alpha$ with some risk factors

\begin{tabular}{|c|c|c|c|c|}
\hline \multicolumn{2}{|c|}{} & No. of pts. & TNF- $\alpha$ & p. value \\
\hline \multirow{3}{*}{ Gender } & Male & $68(54.4)$ & 24.39 & \multirow{2}{*}{0.16} \\
\cline { 2 - 4 } & Female & $57(45.6)$ & 30.70 & \\
\hline \multirow{4}{*}{ Smoker } & Yes & $39(31.2)$ & 27.59 & \multirow{2}{*}{0.80} \\
\cline { 2 - 4 } & No & $67(53.6)$ & 26.51 & \\
\cline { 2 - 4 } & x- smoker & $19(15.2)$ & 30.69 & \\
\hline \multirow{3}{*}{ Obesity } & Yes & $20(16 \%)$ & 32.8 & \multirow{2}{*}{0.25} \\
\cline { 2 - 4 } & No & $105(84)$ & 26.44 & \\
\hline \multirow{3}{*}{ Hypertension } & Yes & $72(57.6)$ & 32.99 & \multirow{2}{*}{0.73} \\
\cline { 2 - 4 } & No & $53(42.2)$ & 28.30 & \\
\hline \multirow{3}{*}{ Family history } & Yes & $65(52)$ & 27.83 & 0.945 \\
\cline { 2 - 4 } & No & $60(48)$ & 27.54 & 0.475 \\
\cline { 2 - 4 } & Yes & $28(23.2)$ & 25.83 & \\
\hline
\end{tabular}




\section{International Journal of Medical Science and Health Research}

Vol. 5, No. 01; 2021

ISSN: 2581-3366

Table 3 The level of TNF- $\alpha$ between patients with complications and patients without complications

\begin{tabular}{|c|c|c|c|c|}
\hline & NO. patients & $\begin{array}{c}\text { Mean of TNF-a } \\
\text { Pg./dl }\end{array}$ & SD & P. value \\
\hline Complication & 36 & 33.46 & 24.91 & 0.041 \\
\hline $\begin{array}{c}\text { Without } \\
\text { complication }\end{array}$ & 89 & 24.15 & 21.93 & \\
\hline
\end{tabular}

Table 4 The mean of TNF- $\alpha$ in patient with complications (HF \&others)

\begin{tabular}{||c||c|c||c||c||}
\hline & NO. of pts. & $\begin{array}{c}\text { TNF- } \alpha \\
\text { (mean } \text { gg/dl) }\end{array}$ & SD & P. value \\
\hline \hline Heart failure & 24 & 35.19 & 26.37 & \\
\hline \hline Other complications & 7 & 36.69 & 26.9 & \multirow{2}{*}{0.897} \\
\hline $\begin{array}{c}\text { Heart failure plus Other } \\
\text { complications }\end{array}$ & 5 & 35.58 & 13.73 & \\
\hline \hline & 36 & 33.46 & 24.911 & \\
\hline Total & 36 & & & \\
\hline
\end{tabular}

Table 5: The mean level of TNF- $\alpha$ among various form of ACS in different gender

\begin{tabular}{|c||c|c|c|c||c||c|}
\hline & Gender & STEMI & NSTEMI & UN & Control & P.value \\
\hline \hline $\begin{array}{c}\text { TNF- } \\
\alpha(\text { mean } \\
\text { pg/dl) }\end{array}$ & Male & 31.20 & 22.01 & 11.17 & 10.47 & \multirow{2}{*}{0.210} \\
\cline { 2 - 6 } & Female & 37.72 & 24.02 & 17.15 & 10.75 & \\
\hline
\end{tabular}

